\title{
Potensi Hasil Galur - Galur Harapan Kedelai Hitam (Glycine max ( L.) Merr.) di Kabupaten Bogor
}

\section{Yield Potential of Black Soybean (Glycine $\underline{\max }$ (L.) Merr.) Lines in Bogor}

\author{
Lela Marlenasari, Desta Wirnas* \\ Departemen Agronomi dan Hortikultura, Fakutas Pertanian, Institut Pertanian Bogor \\ (Bogor Agricultural University), Jln. Meranti, Kampus IPB Dramaga, Bogor 16680, Indonesia \\ Telp.\&Faks. +62-251-8629353 e-mail agronipb@indo.net.id \\ *Penulis untuk korespondensi: desta.wirnas@yahoo.com
}

Disetujui 11 Mei 2015/Published online 18 Mei 2015

\begin{abstract}
The objective of the research was to evaluate yield potential of 8 black soybean (Glycine max (L.) Merr.) lines. The research was conducted at Bogor (West Java) in October 2011 until January 2012 as a part of multilocational trials. Experimental design used was RCBD with replication and three national varieties as control, namely Cikuray, Malika and Willis. The results show that plant height, flowering time and harvesting time, number of productive branch and number of unfilled pod were statically different. SSD-82, SSD-91, and SC-68-2 had higher productivitity than check variety (Cikuray).
\end{abstract}

Keywords : black soybean, single seed descent, yield evaluation

\begin{abstract}
ABSTRAK
Tujuan dari penelitian ini adalah untuk mengevaluasi potensi hasil dari 8 galur harapan kedelai hitam (Glycine max (L.) Merr.). Penelitian ini dilakukan di Bogor (Jawa Barat) pada bulan Oktober 2011 sampai Januari 2012 sebagai bagian dari uji coba multilokasi. Rancangan percobaan yang digunakan adalah rancangan kelompok lengkap teracak dengan pengulangan dan tiga varietas nasional sebagai kontrol, yaitu Cikuray, Malika dan Willis. Hasil penelitian menunjukkan bahwa tinggi tanaman, waktu berbunga dan waktu panen, jumlah cabang produktif dan jumlah polong hampa sceara statistik berbeda. SSD-82, SSD-91, dan SC-68-2 memiliki produktivitas tinggi dibandingkan varietas pembanding (Cikuray).
\end{abstract}

Kata kunci: evaluasi hasil, kedelai hitam, keturunan benih tunggal 


\section{PENDAHULUAN}

Kedelai merupakan salah satu sumber utama protein nabati di Indonesia. Olahan biji kedelai dapat berupa tahu, tempe, kecap, tauco, susu kedelai, tepung kedelai, dan sebagai bahan baku kosmetik. Produk kedelai sebagai bahan olahan pangan berpotensi dan berperan dalam menumbuh kembangkan industri kecil menengah bahkan sebagai komoditas ekspor (Balitan, 2008). Produksi kedelai saat ini sekitar 600 sampai 800 ribu ton per tahun dan hanya memenuhi $40 \%$ kebutuhan nasional selebihnya dipenuhi melalui impor sekitar 1,4 sampai 1,6 juta ton per tahun.

Berdasarkan warna bijinya dikenal kedelai kuning dan kedelai hitam. Menurut Nazar et al. (2008) pemeliharaan kedelai hitam umumnya lebih mudah dari pada kedelai kuning. Kedelai hitam umumnya hanya digunakan untuk bahan baku kecap. Kendala yang dihadapi pada kedelai hitam masih belum mendapat perhatian besar dari peneliti maupun pemerintah. Varietas unggul dari kedelai hitam lebih terbatas dibandingkan dengan kedelai kuning. Periode antara tahun 1918 hingga 2007, hanya lima varietas kedelai hitam dari 44 varietas kedelai yang dilepas.

Melalui pemuliaan tanaman dapat dihasilkan varietas unggul kedelai hitam yang memilki potensi hasil tinggi. Wirnas et al. (2011) melaporkan bahwa sampai saat ini Departemen Agronomi dan Hortikultura telah menghasilkan sejumlah galur - galur kedelai hitam dengan hasil seleksi metode SSD (single seed descent) atau bulk sehingga diperlukan uji daya hasil galur galur kedelai tersebut untuk mendapatkan varietas unggul baru. Penelitian ini bertujuan untuk menguji potensi hasil delapan galur harapan kedelai hitam (Glycine $\max$ (L.) Merr.) hasil pemuliaan Departemen Agronomi dan Hortikultura IPB sebagai bagian dari uji multilokasi di Kabupaten Bogor, Jawa Barat.

\section{BAHAN DAN METODE}

Penelitian ini dilaksanakan pada lahan kering di Muara, Desa Mulyaharja, Kabupaten Bogor Selatan, Jawa Barat dan di Laboratorium RGCI Departemen Agronomi dan Hortikultura IPB. Adapun waktu pelaksanaan penelitian ini yaitu pada bulan Oktober 2011 sampai bulan Januari 2012.

Bahan yang digunakan pada penelitian ini yaitu delapan galur kedelai hitam yang terdiri dari SSD-54, SSD-75, SSD-82, SSD-91, SSD-102, SC-39-1, SC-68-2, GC-74-7, tiga varietas pembanding yaitu Cikuray, Malika dan Willis.
Pupuk kandang dengan dosis 1,5 ton per ha, pupuk dasar urea $30 \mathrm{~kg}$ per ha, SP-36 $150 \mathrm{~kg}$ per ha, $\mathrm{KCl} 75 \mathrm{~kg}$ per ha serta inokulan rhizobium dengan dosis $250 \mathrm{~g}$ per $40 \mathrm{~kg}$ benih dan insektisida karbofuran $3 \mathrm{G}$ dosis $2 \mathrm{~kg}$ per ha.

Rancangan percobaan yang digunakan adalah Rancangan Kelompok Lengkap Teracak (RKLT) dengan galur sebagai perlakuan dengan tiga ulangan. Dalam penelitian ini digunakan delapan galur harapan kedelai hitam dan tiga varietas pembanding, sehingga terdapat 33 satuan percobaan. Ukuran petak untuk setiap satuan percobaan sebesar $4 \mathrm{~m}$ x $5 \mathrm{~m}$. Model rancangan yang digunakan yaitu $\mathrm{Yij}=\mu+\alpha \mathrm{i}+\beta \mathrm{j}+$ eij. Karakter yang sangat nyata dan nyata pada uji $F$ dilanjutkan dengan menggunakan uji Dunnet pada $\alpha=5 \%$.

Penelitian dilaksanakan pada lahan dengan luas $680 \mathrm{~m}^{2}$. Tanah diolah sedalam kurang lebih $30 \mathrm{~cm}$ dengan cara dibalik menggunakan cangkul. Setelah diolah, tanah dicampur pupuk kandang kemudian dibuat petak-petak dengan ukuran $4 \mathrm{~m}$ x $5 \mathrm{~m}$ sebanyak 11 satuan petak percobaan setiap ulangan. Jumlah antar petak dalam ulangan selebar $20 \mathrm{~cm}$ dan jarak antar ulangan $50 \mathrm{~cm}$.

Benih dicampur dengan inokulan rhizobium sebelum ditanam. Aplikasinya menggunakan tepung terigu sebagai bahan perekat dan sedikit air kemudian diaduk bersama benih secara merata. Benih ditanam dengan jarak tanam $20 \mathrm{~cm} \times 25 \mathrm{~cm}$ dengan dua benih per lubang kemudian ditambahkan sedikit insektisida karbofuran 3G pada setiap lubang tanam. Pupuk yang digunakan adalah urea $30 \mathrm{~kg}$ per ha, SP-36 $150 \mathrm{~kg}$ per ha dan $\mathrm{KCl} 75 \mathrm{~kg}$ per ha. Pupuk diberikan pada saat 1 Minggu setelah Tanam (MST) dengan cara dialur pada setiap baris tanaman. Penyiangan dilakukan sebanyak dua kali yaitu pada 16 HST dan ketika tanaman berumur 37 HST. Selama pemeliharaan dilakukan pengendalian hama penyakit.

Panen dilakukan pada tiap petak percobaan. Tanaman dipanen ketika lebih dari 95\% polong berwarna coklat, daun - daun menguning, gugur, dan batang telah kering. Perlakuan setelah panen meliputi penjemuran brangkasan kedelai selama 3-7 hari, kemudian dilakukan pemecahan polong dan biji dikeringkan dengan oven selama 1 hari pada suhu $45{ }^{\circ} \mathrm{C}$ sebelum disimpan.

Pengamatan dilakukan pada setiap petak percobaan dengan komponen yang diamati diantaranya (1) Daya berkecambah benih (\%) yaitu, daya berkecambah benih saat 2 MST, (2) Umur berbunga (HST) yaitu, pada saat $80 \%$ tanaman telah berbunga dalam satuan petak 
percobaan, (3) Umur panen (HST) yaitu, pada saat 95\% polong tanaman berwarna kuning kecoklatan atau daun telah gugur, (4) Bobot biji per ubinan $\left(\mathrm{g} / 4 \mathrm{~m}^{2}\right)$ yaitu, hasil bobot total biji kering panen per ubinan, (5) Rata - rata jumlah biji perpolong, dan (7) Hama, penyakit, dan gulma yang berada di lahan.

Pengamatan pada masing-masing contoh, yaitu dengan mengambil 10 tanaman contoh secara acak pada setiap ulangan. Semua pengamatan dilakukan pada saat panen. Peubahpeubah yang diamati antara lain: (1) Tinggi tanaman saat panen $(\mathrm{cm})$ yaitu, tinggi tanaman dari pangkal batang tanaman sampai titik tumbuh, (2) Jumlah cabang produktif yaitu, jumlah cabang yang menghasilkan polong, (3) Jumlah buku produktif yaitu, jumlah buku yang memiliki polong, (4) Jumlah polong bernas yaitu, jumlah polong yang menghasilkan biji, (5) Jumlah polong hampa yaitu, jumlah polong yang tidak menghasilkan biji, (6) Bobot 100 butir biji kering panen (g), (7) Bobot biji pertanaman (g) yaitu, bobot total biji kering panen per tanaman.

Pendugaan komponen ragam diperoleh dengan cara sebagai berikut :

1. Ragam Lingkungan $\left(\sigma_{\mathrm{e}}^{2}\right)$ merupakan kuadrat tengah galat (N1) atau pengaruh lingkungan yang menyebabkan terjadinya perbedaan penampilan dari karakter-karakter yang diamati, sehingga Ragam Lingkungan $\left(\sigma_{\mathrm{e}}^{2}\right)$

2. Ragam Fenotipik $\left(\sigma_{\mathrm{p}}^{2}\right)$ merupakan hasil pengamatan dilapang dan dapat diduga dari kuadrat tengah galur (N2), karena percobaan diulang sebanyak tiga kali, sehingga $\sigma_{p}^{2}=$ $\mathrm{N} 2 / \mathrm{r}$

3. Ragam Genetik $\left(\sigma_{g}^{2}\right)$ merupakan pengaruh genetik terhadap penampilan dari karakter karakter yang diamati. Ragam genetik dapat diduga dari :

$$
\sigma_{g}^{2}=(\mathrm{N} 2-\mathrm{N} 1) / \mathrm{r}
$$

Nilai Heritabilitas (dalam arti luas) merupakan perbandingan dari ragam genetik terhadap keragaman total dalam populasi dapat diduga dengan perhitungan (Poehlman and Sleper, 1995):

$$
\mathrm{h}_{\mathrm{bs}}^{2}=\sigma_{\mathrm{g}}^{2} / \sigma_{\mathrm{p}}^{2} \mathrm{x} 100 \%
$$

Allard (1960) mengemukakan bahwa setiap sebaran data pada masing-masing karakter pengamatan pada populasi dapat dihitung nilai koefisien keragaman genetiknya (KKG) yang merupakan nisbah antara akar kuadrat tengah ragam genetik dengan rataan umum. Nilai KKG dapat dihitung melalui rumus :

$\mathrm{KKG}=(\sigma g / \mathrm{x}) \times 100 \%$

\section{HASIL DAN PEMBAHASAN}

\section{Keragaan Karakter Agronomi}

\section{Tinggi Tanaman Saat Panen, Jumlah Cabang Produktif dan Jumlah Buku Produktif}

Karakter tinggi tanaman pada saat panen galur-galur kedelai hitam berkisar antara $72-104$ $\mathrm{cm}$ dengan nilai tengah $84.1 \mathrm{~cm}$ (Tabel 1). Karakter tinggi tanaman saat panen untuk varietas pembanding berkisar antara 64.95 - 90.25 dengan nilai tengah $78.28 \mathrm{~cm}$. Tinggi tanaman kedelai ideal di lahan kering adalah $70-80 \mathrm{~cm}$ (Arsyad et al., 2007). Varietas Cikuray memiliki tinggi tanaman yang ideal jika dibandingkan dengan varietas Malika dan Willis sehingga varietas tersebut menjadi pembanding dalam karakter tinggi tanaman.

Tabel 1. Nilai rataan dan standar deviasi karakter tinggi tanaman, jumlah cabang produktif, dan jumlah buku produktif galur harapan kedelai hitam di lahan kering

\begin{tabular}{cccc}
\hline Galur Kedelai & Tinggi Tanaman $(\mathrm{cm})$ & Jumlah Cabang Produktif & Jumlah Buku Produktif \\
\hline SSD-54 & $86.3 \pm 4.2$ & $3.5 \pm 0.3$ & $19.53 \pm 2.06$ \\
SSD-75 & $91.2 \pm 11.1^{* *}$ & $3.4 \pm 0.5$ & $19.83 \pm 2.27$ \\
SSD-82 & $74.9 \pm 2.5$ & $2.9 \pm 0.5$ & $17.20 \pm 2.40$ \\
SSD-91 & $82.6 \pm 7.3$ & $3.6 \pm 0.9$ & $18.80 \pm 0.75$ \\
SSD-102 & $86.8 \pm 4.4$ & $2.5 \pm 0.3$ & $15.67 \pm 0.75$ \\
SC-39-1 & $76.7 \pm 5.3$ & $2.2 \pm 0.4$ & $16.23 \pm 1.82$ \\
SC-68-2 & $89.8 \pm 2.3^{* *}$ & $2.7 \pm 0.3$ & $17.47 \pm 1.25$ \\
GC-74-7 & $84.6 \pm 6.9$ & $1.7 \pm 0.8$ & $15.60 \pm 2.12$ \\
\hline Rata-Rata & $84.1 \pm 5.8$ & $2.8 \pm 0.7$ & $17.54 \pm 1.69$ \\
\hline Cikuray & $75.18 \pm 8.97$ & $2.53 \pm 0.99$ & $17.17 \pm 3.52$ \\
Malika & $80.88 \pm 8.13$ & $2.77 \pm 0.45$ & $19.90 \pm 2.18$ \\
Willis & $78.77 \pm 10.23$ & $2.30 \pm 0.56$ & $17.71 \pm 1.97$ \\
\hline Rata-Rata & $78.28 \pm 2.88$ & $2.53 \pm 0.23$ & \\
\hline
\end{tabular}

Keterangan: Angka yang diiukuti * berbeda nyata dengan varietas pembanding Cikuray dan Malika berdasarkan uji Dunnet pada taraf $5 \%$ 
Galur SSD-54, SSD-82, SSD-91, SSD102, SC-39-1 dan GC-74-7 memiliki tinggi tanaman yang mendekati ideal sama dengan varietas cikuray.Galur - galur yang diuji mengalami penurunan daripada populasi pada lahan kering yang diuji oleh Rohaeni (2010) yang memiliki kisaran tinggi antara 67.7 - 94.74 dengan nilai tengah yaitu $79.51 \mathrm{~cm}$. Tinggi tanaman berkorelasi positif dengan karakter komponen hasil seperti jumlah cabang produktif, jumlah buku produktif, jumlah polong total jumlah polong bernas, jumlah polong hampa, bobot biji per tanaman, rata - rata jumlah polong dan umur panen.

Rata - rata jumlah cabang produktif pada galur -galur kedelai hitam yaitu 2.83 dengan kisaran 1.67 (GC-74-7) - 3.63 (SSD-91) sementara rata - rata jumlah cabang produktif pada varietas pembanding yaitu 2.53 dengan kisaran 2.3 - 2.77 cabang. Arsyad et al. (2007) melaporkan bahwa jumlah cabang ideal tanaman kedelai pada lahan kering mencapai 4 - 5 cabang. Malika memiliki jumlah cabang lebih banyak dari rata - rata jumlah cabang varietas pembanding sehingga Malika (2.77 cabang) dijadikan sebagai pembanding dalam karakter jumlah cabang produktif. Galur - galur yang diuji memiliki jumlah cabang yang sama dengan pembanding. Beberapa galur memiliki nilai tengah cabang produktif yang lebih besar jika dibandingkan dengan Malika yaitu SSD-54 (3.5), SSD-91 (3.6) dan SSD-75 (3.4).

Kisaran jumlah buku produktif pada galur-galur kedelai hitam berada pada rentang 15.6 (GC-74-7) - 19.83 (SSD-75) dengan ratarata sekitar 17.54. SSD-102 dan GC-74-7 memiliki rata - rata jumlah buku produktif paling rendah yaitu masing-masing 15.67 dan 15.60 sementara SSD-54 dan SSD-75 memiliki nilai tengah tertinggi yaitu 19.53 dan 19.83. Rata - rata jumlah buku produktif pada varietas pembanding Cikuray, Malika dan Willis adalah 16.07, 17.17, dan 19.90 dengan rataan 17.71.Galur - galur pada penelitian ini memiliki jumlah buku lebih rendah bila dibandingkan dengan populasi yang diuji sebelumnya.

Jumlah Polong Total, Jumlah Polong Bernas, Jumlah Polong Hampa, dan Rata-rata Jumlah Biji per Polong

Polong total pada galur yang diuji ratarata berkisar 85.36 sementara kisaran dari polong total yang teramati yaitu $75.92-97.83$ sementara nilai tengah jumlah polong total dari varietas pembanding Cikuray, Malika dan Willis yaitu $79.08,74.5$ dan 83.17 sehingga rataan jumlah polong total untuk varietas pembanding yaitu 78.28 (Tabel 2). Hasil ini lebih sedikit jika dibandingkan dengan penelitian Lestarina (2010) dilahan sawah dimana rata-rata jumlah polong total untuk galur yang diuji yaitu 95.0 dengan kisaran 58.1 - 130.3 sedangkan rataan untuk Cikuray 89.0, dan Willis 84.0.

Jumlah polong bernas merupakan output yang diharapkan dari tanaman kedelai ini. Peubah ini menunjukan nilai ekonomi yang dapat diperoleh dari tanaman kedelai. Kisaran jumlah polong bernas tanaman kedelai berkisar antara 33 hingga 64 buah dengan rata - rata 48 polong (Adie dan Ayda, 2007). Jumlah polong bernas pada galur - galur dan varietas pembanding yang diuji berkisar antara 67.23 - 89.97 dimana galur - galur yang diuji memiliki nilai tengah 79.25 sementara nilai tengah dari varietas pembanding yaitu 75.39 dengan masing - masing rataan yaitu Cikuray 70.88, Malika 78.37 dan Willis 76.93 (Tabel 2).

Tabel 2. Nilai rataan dan standar deviasi karakter jumlah polong total, jumlah polong bernas, jumlah polong hampa dan rata - rata jumlah biji/polong galur harapan kedelai hitam di lahan kering

\begin{tabular}{ccccc}
\hline Karakter & Jumlah Polong Total & Jumlah Polong Bernas & $\begin{array}{c}\text { Jumlah Polong } \\
\text { Hampa }\end{array}$ & $\begin{array}{c}\text { Rata-Rata Jumlah } \\
\text { Biji/Polong }\end{array}$ \\
\hline SSD-54 & $97.8 \pm 6.6$ & $87.3 \pm 13.3$ & $6.2 \pm 1.4^{*}$ & $2.1 \pm 0.03$ \\
SSD-75 & $86.9 \pm 7.3$ & $89.97 \pm 0.1$ & $4.8 \pm 0.4$ & $2.1 \pm 0.06$ \\
SSD-82 & $88.2 \pm 12.3$ & $78.7 \pm 12.6$ & $5.1 \pm 1.2$ & $2.2 \pm 0.18$ \\
SSD-91 & $79.1 \pm 6.6$ & $77.73 \pm 5.5$ & $5.9 \pm 2.0$ & $2.2 \pm 0.17$ \\
SSD-102 & $80.3 \pm 11.5$ & $76.43 \pm 5.6$ & $3.5 \pm 0.9$ & $2.2 \pm 0.07$ \\
SC-39-1 & $75.9 \pm 8.4$ & $67.23 \pm 8.7$ & $5.7 \pm 2.9$ & $2.2 \pm 0.16$ \\
SC-68-2 & $96.5 \pm 13.6$ & $87.07 \pm 7.4$ & $6.2 \pm 1.4^{*}$ & $1.9 \pm 0.19$ \\
GC-74-7 & $88.3 \pm 20.1$ & $69.50 \pm 9.9$ & $5.9 \pm 1.5$ & $2.1 \pm 0.15$ \\
\hline Rata-Rata & $85.4 \pm 8.4$ & $79.3 \pm 8.4$ & $5.4 \pm 0.9$ & $2.1 \pm 0.06$ \\
\hline Cikuray & $77.2 \pm 8.1$ & $70.9 \pm 9.4$ & $2.5 \pm 0.5$ & $2.1 \pm 0.06$ \\
Malika & $74.5 \pm 5.1$ & $78.4 \pm 8.3$ & $3.9 \pm 1.3$ & $2.0 \pm 0.08$ \\
Willis & $83.2 \pm 19.3$ & $76.9 \pm 17.8$ & $2.7 \pm 1.6$ & $2.1 \pm 0.09$ \\
\hline Rata-Rata & $78.3 \pm 4.4$ & $75.4 \pm 3.9$ & $3.01 \pm 0.8$ & $2.0 \pm 0.06$ \\
\hline
\end{tabular}

Keterangan : Angka yang diiukuti * berbeda nyata dengan varietas pembanding Cikuray berdasarkan uji Dunnet pada taraf $5 \%$ 
Hasil jumlah polong bernas ini lebih sedikit jika dibandingkan dengan penelitian Rohaeni (2010), dilahan kering dimana rataan dari galur yang diuji sebesar 82.97 dan penelitian Lestarina (2010) yang memiliki nilai tengah 92.6 tetapi hasil ini lebih tinggi jika dibandingkan dengan penelitian Komara (2010) dilahan sawah yang memiliki nilai tengah 78.7 .

Jumlah polong hampa pada galur-galur yang diuji berkisar antara $3.53-6.23$ (Tabel 2) dengan nilai tengah 5.41 sedangkan nilai tengah varietas yang diuji yaitu 3.01 (Tabel 3). Semakin banyak jumlah polong hampa maka semakin rendah produktivitas yang dihasilkan, sehingga jumlah polong hampa tidak diharapkan dalam penelitian ini. Galur SSD-75, SSD-82, SSD-91, SSD-102, SC-39-1dan GC-74-7 menunjukan jumlah polong hampa yang setara dengan Cikuray (2.50).

Karakter rata - rata jumlah biji pertanaman merupakan salah satu komponen hasil yang menentukan produktivitas. Rata-rata jumlah biji perpolong ini didapat dari hasil bagi antara jumlah biji pertanaman dengan jumlah polong total. Hidajat (2008) melaporkan bahwa tiap polong kedelai dapat berisi satu sampai lima biji, tapi umumnya berisi dua sampai tiga biji. Hasil yang diperoleh rata - rata jumlah biji per polong dari galur-galur dan varietas yang diuji berkisar antara 1.95 - 2.25 biji per polong. Galur-galur yang diuji memiliki nilai tengah 2.14 sementara varietas pembanding memiliki nilai tengah 2.01 (Tabel 2).

Bobot Biji Per Tanaman, Bobot 100 butir dan Potensi Hasil Per Tanaman

Bobot biji per tanaman pada penelitian ini berkisar antara 14.22 (GC-74-7) -19.3 (SSD-54) g dengan nilai tengah dari galur-galur yang diuji yaitu $16.84 \mathrm{~g}$ sementara nilai tengah dari varietas pembanding adalah 15.31 g. Bobot biji per tanaman yang diperoleh pada penelitian ini lebih tinggi jika dibandingkan dengan penelitian Rohaeni (2010) dilahan kering mendapatkan nilai tengah bobot biji per tanaman untuk galur yang diseleksi dengan SSD sebasar 12.80 dengan kisaran 9.06-19.30 begitupun jika dibandingkan dengan penelitian Komara (2010) dilahan sawah mendapatkan nilai tengah galur - galur yang diuji untuk bobot biji per tanaman yaitu $14.7 \mathrm{~g}$ dengan kisaran 9.7-23.7 g.

Bobot 100 butir tanaman pada galur galur yang diuji berkisar antara $9.66-10.92 \mathrm{~g}$ dengan rata - rata $10.18 \mathrm{~g}$ sementara rataan bobot 100 butir pada varietas pembanding yaitu $10.30 \mathrm{~g}$ dengan masing-masing memiliki nilai Cikuray $10.26 \mathrm{~g}$, Malika $10.09 \mathrm{~g}$ dan Willis $10.57 \mathrm{~g}$. Pengelompokan ukuran biji kedelai di Indonesia terdiri dari berukuran besar (berat $>14 \mathrm{~g}$ per 100 biji), sedang (10-14 g per 100 biji) dan kecil $(<10$ g per 100 biji) (Adie et al., 2007). Berdasarkan pengelompokan tersebut dapat dikatakan galur galur yang diuji berukuran sedang.

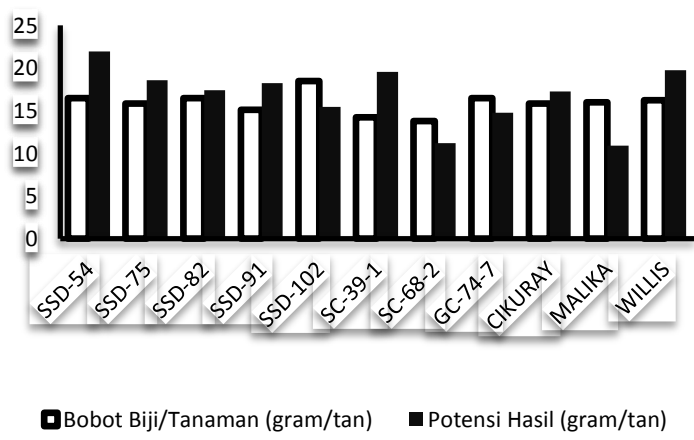

Gambar 1. Bobot biji pertanaman dan potensi hasil pada galur - galur kedelai yang diuji dan varietas pembanding

Tabel 3. Nilai rataan dan standar deviasi karakter bobot biji per tanaman (g), bobot 100 biji (g), dan potensi hasil (g) galur harapan kedelai hitam di lahan kering

\begin{tabular}{|c|c|c|c|}
\hline Galur Kedelai & Bobot Biji/ Tanaman & Bobot 100 Butir & Potensi Hasil \\
\hline SSD-54 & $19.30 \pm 3.7$ & $10.55 \pm 0.4$ & $21.93 \pm 1.9$ \\
\hline SSD-75 & $18.90 \pm 0.5$ & $10.43 \pm 0.5$ & $18.75 \pm 2.1$ \\
\hline SSD-82 & $16.47 \pm 2.7$ & $9.97 \pm 0.7$ & $18.32 \pm 1.3$ \\
\hline SSD-91 & $15.82 \pm 0.9$ & $9.66 \pm 0.8$ & $16.07 \pm 3.3$ \\
\hline SSD-102 & $16.47 \pm 1.6$ & $10.13 \pm 0.1$ & $17.58 \pm 3.0$ \\
\hline SC-39-1 & $15.09 \pm 2.0$ & $10.92 \pm 0.3$ & $18.23 \pm 3.0$ \\
\hline SC-68-2 & $18.46 \pm 2.6$ & $10.05 \pm 0.5$ & $17.43 \pm 6.2$ \\
\hline GC-74-7 & $14.22 \pm 2.5$ & $9.71 \pm 0.3$ & $14.59 \pm 1.2$ \\
\hline Rata-Rata & $16.84 \pm 1.9$ & $10.18 \pm 0.4$ & $17.86 \pm 3.1$ \\
\hline Cikuray & $13.77 \pm 3.0$ & $10.26 \pm 0.1$ & $15.42 \pm 1.9$ \\
\hline Malika & $15.96 \pm 1.3$ & $10.09 \pm 0.8$ & $15.22 \pm 1.6$ \\
\hline Willis & $16.21 \pm 1.6$ & $10.57 \pm 0.6$ & $18.09 \pm 4.7$ \\
\hline Rata-Rata & $15.31 \pm 1.3$ & $10.30 \pm 0.2$ & $16.24 \pm 4.6$ \\
\hline
\end{tabular}


Potensi hasil per tanaman galur - galur kedelai yang diuji merupakan konversi dari jumlah biji per tanaman dikalikan dengan berat biji per satuan biji yang diperoleh dari bobot 100 butir dibagi 100 biji. Potensi hasil pada galur yang diuji berkisar antara $14.59 \mathrm{~g}$ per tanaman (GC-747) sampai 21.93 (SSD-54) dengan nilai tengah $17.86 \mathrm{~g}$ per tanaman. Sementara potensi hasil pada varietas pembanding Cikuray, Wilis dan Mallika yaitu 15.42, 15.22, dan 18.09 dengan nilai tengah $16.24 \mathrm{~g}$ per tanaman.

Potensi hasil ini jika dibandingkan dengan bobot biji per tanaman (Gambar 1) terlihat hampir semua galur - galur yang diuji dan varietas pembanding yang digunakan hampir mencapai potensi yang maksimal terkecuali pada galur SC-68-2 dan Malika yang memiliki bobot biji tanaman melebihi potensi maksimalnya yakni 18.46 dan $15.96 \mathrm{~g}$ dengan potensi hasilnya 17.43 dan $15.22 \mathrm{~g}$ per tanaman (Tabel 3). Faktor iklim dan kesesuaian lahan yang kurang optimum menyebabkan bobot biji pertanaman belum mencapai potensi hasil maksimalnya karena akumulasi dalam pembentukan biji kurang optimal.

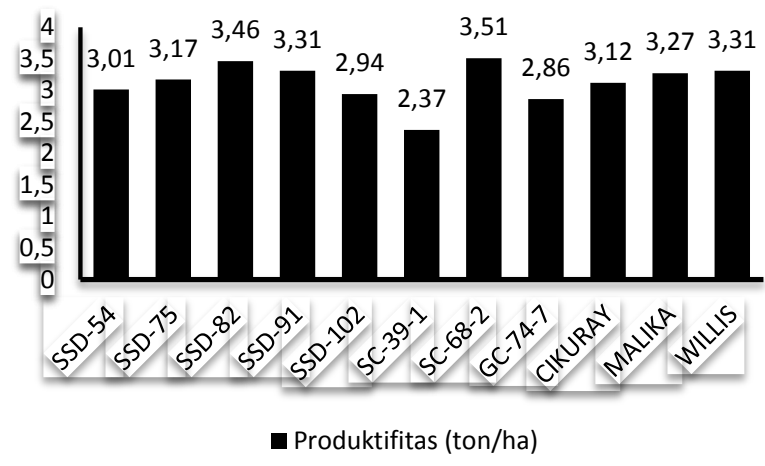

Gambar 2. Grafik produktivitas galur - galur kedelai hitam yang diuji dan varietas pembanding

Produktivitas kedelai didapat dari konversi dari bobot ubinan ( $2 \mathrm{~m} \times 2 \mathrm{~m}$ ). Gambar 2 menunjukkan galur - galur kedelai hitam yang diuji memiliki rata - rata produktivitas 3.08 ton per ha sedangkan rata-rata produktivitas dari ketiga pembanding yaitu sekitar 3.23 ton per ha. Galur - galur yang diuji sudah memiliki nilai produktivitas yang sebanding dengan dengan varietas yang diuji begitupun dengan komponen hasil lainnya seperti bobot biji per tanaman, bobot 100 butir dan potensi hasil per tanamannya.

\section{Umur Berbunga dan Umur Panen}

Umur berbunga ditetapkan ketika $80 \%$ per satuan petakan telah berbunga. Adie et al. (2007) melaporkan bahwa periode berbunga dipengaruhi oleh waktu tanam dan berlangsung 3 - 5 MST. Sebagian besar populasi galur mulai berbunga pada 43 HST. Galur-galur kedelai hitam ini rata rata memiliki karakter umur berbunga yaitu 45.79 dengan kisaran umur berbunga 43 - 49 sementara varietas Cikuray, Malika dan Willis rata - rata umur berbunganya adalah 47.0, 44.3 dan 48.3 HST (Tabel 4).

Umur berbunga yang lebih cepat akan menghasilkan polong lebih cepat sehingga diharapkan galur - galur yang diuji memiliki umur berbunga yang lebih cepat pula. Malika memiliki umur berbunga yang lebih pendek dari varietas pembanding lainnya sehingga dijadikan pembanding pada karakter umur berbunga. Galur - galur yang diuji memiliki umur berbunga sama cepatnya dengan varietas Malika (44.3 HST) kecuali galur SC-39-1, GC-74-7 dan Willis memiliki umur berbunga yang lebih lama.

Umur panen galur kedelai berkisar antara 92.7 - 100 HST dengan rataan umur panen galur yang diuji yaitu 46.21 HST. Nilai tengah dari umur panen varietas Cikuray adalah 90.0 HST. Varietas Cikuray memiliki umur panen lebih pendek dari tiga varietas lainnya. SSD-54, SSD75,SSD-102, SSD-82, SSD-91, SC-68-2 dan Malika memiliki umur panen yang lebih cepat seperti Cikuray.

Umur tanaman kedelai dikelompokan menjadi genjah ( $<80$ hari), sedang ( 80 - 85 hari) dan dalam ( $>85$ hari) (Adie et al., 2007). Jika dilihat dari pengelompokan tersebut maka galur galur kedelai hitam yang diuji memiliki umur yang dalam karena lebih dari 85 hari.

Tabel 4. Nilai rataan dan standar deviasi karakter umur berbunga dan umur panen galur harapan kedelai hitam di lahan kering

\begin{tabular}{clc}
\hline Galur Kedelai & $\begin{array}{c}\text { Umur Berbunga } \\
(\text { HST })\end{array}$ & $\begin{array}{c}\text { Umur Panen } \\
(\text { HST })\end{array}$ \\
\hline SSD-54 & $44.3 \pm 1.2$ & $98.0 \pm 3.5^{* *}$ \\
SSD-75 & $43.7 \pm 24.8$ & $96.0 \pm 3.5^{* *}$ \\
SSD-82 & $45.7 \pm 2.3$ & $94.0 \pm 0.0$ \\
SSD-91 & $45.0 \pm 2.0$ & $92.7 \pm 2.3$ \\
SSD-102 & $43.0 \pm 0.0$ & $94.0 \pm 0.0$ \\
SC-39-1 & $49.0 \pm 1.7 * *$ & $100 \pm 0.0^{* *}$ \\
SC-68-2 & $45.7 \pm 2.3$ & $96.0 \pm 3.5^{* *}$ \\
GC-74-7 & $47.7 \pm 1.2^{* *}$ & $100 \pm 0.0^{* *}$ \\
\hline Rata-rata & $46.2 \pm 2.4$ & $96.3 \pm 2.8$ \\
\hline Cikuray & $47.0 \pm 2.0$ & $90.0 \pm 0.0$ \\
Malika & $44.3 \pm 1.2$ & $92.7 \pm 0.0$ \\
Willis & $48.3 \pm 1.2 * *$ & $100 \pm 2.3 * *$ \\
\hline Rata-Rata & $48.6 \pm 4.3$ & $94.2 \pm 5.2$ \\
\hline Keterangan: Angka yang diiukuti $* *$ berbeda nyata dengan \\
\multicolumn{2}{c}{ varietas pembanding Cikuray dan Malika } \\
berdasarkan uji Dunnet pada taraf 5\%
\end{tabular}


Keragaman Genetik

Menurut Alnopri (2004), luas sempitnya nilai koefisien keragaman dibagi menjadi tiga, yaitu sempit (0-10\%), sedang (10-20\%), dan luas $(>20 \%)$. Berdasarkan pengelompokkan tersebut, galur kedelai yang diuji memiliki nilai KKG sempit yaitu pada karakter tinggi tanaman, jumlah buku produktif, jumlah polong total, jumlah polong bernas, rata - rata jumlah biji per polong, bobot biji per tanaman, bobot 100 butir, umur berbunga dan umur panen. Karakter - karakter tersebut diantara galur dan varietas yang diuji keragamannya kecil. Karakter jumlah cabang produktif dan jumlah polong hampa memiliki nilai KKG sedang yang berarti bahwa karakter karakter tersebut memiliki keragaman yang cukup tinggi.

Tabel 5. Nilai komponen ragam, heritabilitas, dan kriteria heritabilitas

\begin{tabular}{lrrrcc}
\hline \multicolumn{1}{c}{ Karakter } & \multicolumn{1}{c}{$\sigma_{\mathrm{e}}^{2}$} & \multicolumn{1}{c}{$\sigma_{\mathrm{p}}^{2}$} & $\sigma_{\mathrm{g}}^{2}$ & $\mathrm{~h}_{\text {bs }}^{2}$ & $\mathrm{KKG}$ \\
\hline Tinggi Tanaman & 25.46 & 49.71 & 24.25 & 0.49 & 0.06 \\
Jumlah Cabang Produktif & 0.34 & 0.58 & 0.24 & 0.42 & 0.18 \\
Jumlah Buku Produktif & 4.08 & 5.50 & 1.42 & 0.26 & 0.07 \\
Jumlah Polong Total & 148.42 & 163.54 & 15.11 & 0.09 & 0.05 \\
Jumlah Polong Bernas & 93.68 & 121.62 & 27.94 & 0.23 & 0.07 \\
Jumlah Polong Hampa & 2.25 & 3.46 & 1.21 & 0.35 & 0.23 \\
Rata-Rata Jumlah Biji/Polong & 0.02 & 0.02 & 0.00 & 0.06 & 0.02 \\
Bobot Biji/Tanaman & 5.53 & 6.98 & 1.45 & 0.21 & 0.07 \\
Bobot 100 Butir & 0.27 & 0.32 & 0.06 & 0.18 & 0.02 \\
Potensi Hasil & 127.1 & 321.2 & 194.13 & 0.60 & 1.05 \\
Umur Berbunga & 1.69 & 5.02 & 3.33 & 0.66 & 0.04 \\
Umur Panen & 4.15 & 14.52 & 10.38 & 0.71 & 0.03 \\
\hline
\end{tabular}

Keterangan: $\sigma^{2} \mathrm{e}=$ ragam lingkungan. $\sigma^{2} \mathrm{p}=$ ragam fenotifik. $h^{2} \mathrm{bs}=$ nilai heritabilitas. $\mathrm{KKG}=$ Koefisien Keragaman Genetik

Besar kecilnya nilai heritabilitas erat hubungannya dengan kemampuan tanaman untuk melakukan perbaikan sifat melalui seleksi tanaman tersebut serta keturunan generasi berikutnya. Heritabilitas dibagi kedalam tiga kelompok yaitu : rendah $\left(\mathrm{h}^{2} \leq 20 \%\right)$, sedang $(20 \%$ $\leq \mathrm{h}^{2} \geq 50 \%$ ), dan tinggi $\left(\mathrm{h}^{2} \geq 50 \%\right.$ ) (Stanfield, 1983).

Tabel 5 menunjukkan bahwa nilai heritabilitas jumlah polong total, rata - rata jumlah biji per polong dan bobot 100 butir memiliki nilai heritabilitas rendah yakni $0.09,0.06$, dan 0.18 . Nilai heritabilitas sedang ditunjukkan oleh beberapa karakter yaitu pada karakter tinggi tanaman saat panen, jumlah cabang dan buku produktif, jumlah polong bernas, jumlah polong hampa dan bobot biji per tanaman dengan nilai masing - masing yaitu 0.49, 0.42, 0.26, 0.23, 0.35, dan 0.21 sedangkan pada karakter potensi hasil, umur berbunga dan umur panen memiliki nilai heritabilitas tinggi yang berarti karakter tersebut penampilan fenotipenya banyak dikendalikan oleh faktor genotipe dibandingkan dengan faktor lingkungan.

\section{KESIMPULAN}

Karakter tinggi tanaman saat panen, umur berbunga, dan umur panen antar galur yang diuji menunjukan hasil yang sangat nyata. Perbedaan yang nyata terdapat pada karakter jumlah cabang produktif dan jumlah polong hampa. Berdasarkan hasil penelitian dapat disimpulkan bahwa tidak terdapat perbedaan hasil di antara galur - galur yang diuji. Penelitian ini menunjukan bahwa galur - galur yang diuji sudah memiliki potensi hasil yang tinggi. Galur - galur SSD-82, SSD-91 dan SC-68-2 memiliki rata-rata hasil lebih tinggi dari varietas Cikuray.

\section{DAFTAR PUSTAKA}

Adie, M. M., Ayda, K. 2007. Biologi tanaman kedelai. Di Dalam: Sumarno, Suyamto, A. Widjono, Hermanto, Kasim, H., editors. Kedelai. Malang (ID): Badan Penelitian dan Pengembangan Pertanian. hlm 45-73.

Adie, M.M., Susanto, G.W. A., Arifin. 2007. Galur harapan kedelai hitam berdaya hasil tinggi dan berkarakter eksotik. Buletin Palawija (14):1-7.

Allard, R. W. 1960. Principles of Plant Breeding. New York (US): Jhon Wiley and Sons, Inc.

Alnopri. 2004. Viabilitas genetik dan heritabilitas sifat-sifat pertumbuhan bibit tujuh genotipe kopi robusta-arabica. Jurnal Ilmu-ilmu Pertanian Indonesia 6(2):91-96. 
Arsyad, D. M., Muchlish, M. A., Kuswantoro, H. 2007. Perakitan Varietas Unggul Kedelai Spesifik Agroekologi. Malang (ID): Balai Penelitian Tanaman Kacang-kacangan dan Umbi-umbian.

[Balitan] Badan Penelitian dan Pengembangan Pertanian. 2008. Ketersediaan teknologi dalam mendukung peningkatan produksi kedelai menuju swasembada. Siaran Pers:1-4.

Hidajat, O. O. 1985. Morfologi tanaman kedelai. Di Dalam: Somaatmadja, S., Ismunadji, M., Sumarno, Syam, M., Manurung, S.O., Yuswadi, editors. Kedelai. Bogor (ID): Badan Penelitian dan Pengembangan Pertanian. hlm 73-101

Komara, A. 2010. Uji daya hasil galur-galur harapan kedelai hitam (Glycine max (L.) Merr) pada lahan sawah di Kabupaten Majalengka [skripsi]. Bogor (ID): Institut Pertanian Bogor.

Lestarina, L. 2010. Uji daya hasil galur-galur harapan kedelai hitam (Glycine max (L.) Merr) pada lahan sawah di Kabupaten Sumedang, Jawa Barat [skripsi]. Bogor (ID): Institut Pertanian Bogor.
Nazar, A., Mustikawati, D.R, Yani, A. 2008. Teknologi Budidaya Kedelai. Balai Besar Pengkajian dan Pengembangan Teknologi Pertanian. Badan Penelitian dan Pengembangan Pertanian. Seri buku inovasi: TP/02/2008.

Poehlman, J., Sleper, D.A. 1995. Field Crops Fourth Edition. Ames: Iowa State University Press.

Rohaeni, W. R. 2010. Pendugaan parameter genetik dan seleksi RILs F6 kedelai hasil SSD untuk toleransi terhadap intensitas cahaya rendah [tesis]. Bogor (ID): Institut Pertanian Bogor.

Stanfield, W. D. 1983. Teori dan Soal-soal Genetika. Apandi, M., Hardy, L. T., penerjemah. Jakarta (ID): Penerbit Erlangga.

Wirnas, D., Trikoesoemaningtyas, Sutjahjo, S.. 2011. Multilocational trial and yield stability test of soybean. Laporan hasil penelitian I-Mhere B2C. Lembaga Penelitian dan Pengabdian pada Masyarakat, Bogor (ID): Institut Pertanian Bogor. 